[Beer, A. (2004). Education Reform in Quebec: Pluralism and Citizenship. New Zealand Annual Review of Education, 13, 105-126]

\section{Education Reform in Quebec: Pluralism and Citizenship}

\section{ANN BEER}

\section{Abstract:}

This article provides a brief overview of current educational reform in Quebec, Canada, with a special focus on pluralism and citizenship. The article is organized into the following sections: culture and education in Quebec: a historical perspective; the reform - an overview; curriculum reform; teacher education reform; the challenge of rights, recognition, and school practice: questions for the future.

n 1997 I was working with a group of Inuit teacher educators on Baffin Island, directly north of Quebec. I was invited to supper at the home of Elisapee, one of the group. The conversation was held in English rather than Inuktitut out of consideration for me, the Southern visitor, and turned to the subject of outsiders who come to the Arctic. Elisapee commented on the strange way some visitors become fascinated with the Canadian North and sometimes, after only brief visits, feel they can write about it with the tone of an expert. "If they stay a week, they write an article. If they stay a month, they write a book," she said, in a kindly but amused tone. Everyone laughed. Elisapee paused a moment, then continued thoughtfully: "If they stay a year or more, they often don't write anything at all. They finally realize it's far too difficult to explain how complicated things are."

With this incident in mind, it takes a considerable degree of nerve for an outsider, even a long-term resident, to write about educational reform, culture and language in Quebec. In this article Ican only proceed by recognizing that my perspective will inevitably be shaped by my background, that of someone born and brought up in England, but of English/Welsh family, who also spent the
106 Ann Beer

equivalent of a full year in France early in adult life, and a year in English Canada, studying in Toronto. My $\mathrm{PhD}$ was on French-English bilingualism, which made Quebec an intriguing place for me before I became a resident. I have lived in Quebec for the last twenty-one years, and in the 1980s taught in both French and English high schools and the CEGEP (College) system. ${ }^{1}$ Since 1988, I have worked at McGill University in Montreal. As a university teacher I have had an opportunity to serve on various education committees in both English and French. This, perhaps helped by a detachment that comes from having arrived in this culture as an outsider but with adequate fluency in both languages, has led to a particular interest in the way educational reform is occurring here.

The aim of this article is simply to offer an overview of the Quebec Education Reform. There is no neutral or objective position on these issues in the Quebec context. Many people identify strongly with one perspective or another, based on their own ethnicity, region, socio-economic background, language and education. A sample set of readings from books on Quebec history or education written in the two languages - and now the broadening perspectives of indigenous peoples' studies and ethnicity studies - shows the pluralist society at work: there is often no consensus. All I have attempted to do here is to provide a view that at least seeks balance. I can only apologise for the over-simplifications and shortcomings that are almost inevitable in such an overview.

The reform has been developed in a context of cultural, linguistic and educational complexity. Indeed, "1'approche culturelle" has been one of the key concepts (Gouvernement du Québec, 2001a, p. 33, French version). Given that there are many interwoven elements, I have chosen to focus on one major theme, the challenge of pluralism. This is a daily reality in a society that works mainly in French (a language seen by many of its speakers as under threat from the far greater power of English) but also receives large numbers of immigrants and refugees from diverse backgrounds. How are their needs to be balanced? I focus on two parts of the change process: the curriculum reform in schools, and the reform of teacher education that goes with it. Other issues, such as renewed support for vocational education, greater autonomy for schools in terms of governance, and changes in adult education, are equally intriguing but beyond the scope of this text. (Further references can be found through the website of the Ministère de l'Éducation du 
Québec and its many publications; (Gouvernement du Québec, 2004c).

To preface the discussion, here is a statement by Charles Taylor an internationally known philosopher and a bilingual Montrealer:

A number of strands in contemporary politics turn on the need, sometimes the demand, for recognition.... [O]ur identity is partly shaped by recognition or its absence, often by the misrecognition of others, and so a person or group of people can suffer real damage, real distortion, if the people or society around them mirror back to them a confining or demeaning or contemptible picture of themselves. Nonrecognition or misrecognition can inflict harm, can be a form of oppression, imprisoning someone in a false, distorted, and reduced mode of being.... Due recognition is not just a courtesy we owe people. It is a vital human need. (Taylor, 1994, pp. 25-26)

Challenges concerning identity and recognition, that "vital human need", are crucial in Quebec and constantly under discussion. Of course, these challenges are also arising globally, with changing political and economic practices; indigenous peoples' rights; population movement; the digital revolution in communication and knowledge production; and concerns with citizenship in local, national and international communities.

A relatively well-developed democratic society such as Quebec has little choice but to confront the challenges that exist in dealing with the rights and recognition of its constituent cultural groups. One remarkable feature is how far Quebec has come towards being a contemporary society, with high levels of education, in a relatively short time. The Quebec of the 1950s and earlier was a very different place, which had not had a tradition of universal government-run public education, even at elementary level. For many years most of the francophone majority did not have the opportunity to improve their levels of education, employment and pay. Only a small elite group of students went to the "Colleges classiques" that gave a rigorous academic education. Even that education was strongly focused towards the classics, religious studies, philosophy, history and literature. The English Protestant public school system, though smaller, was well-established at the same time. It was strongly supported by its community and had close links with the rest of Canada and the English-speaking world. Education in scientific and commercial areas developed much more rapidly among the anglophone population. Industrial development was often in the hands of English-speaking entrepreneurs who formed a wealthier minority with great power (Henchey \& Burgess, 1987; Henchey, 1999; Graveline, 2003).

This meant that many francophones found themselves in a humiliating position - though a majority in the province, they were the ones compelled to become bilingual if they could, and few could aspire to professional or leadership roles. The English-speaking employers often did not feel it necessary to learn French, and if they did so, many despised Quebec French, preferring the (to them) more elegant international French of Paris (de Mejia, 2002). The Roman Catholic Church had enormous authority in francophone culture, including control over health, education and social welfare, such as the care of orphans and the handicapped. This control finally ended in the 1960s. The "Parent Report" of 1963-1966 recommended huge changes in education, and was a central influence in the "Quiet Revolution" which transformed Quebec society (Gouvernement du Québec, 1963-1966; Henchey, 1999). Jean Lesage's government took control of what had generally been the prerogatives of the Church. The Ministry of Education was established in 1964, and has become a powerful force in Quebec life.

Paradoxically, Quebec society may have some advantages in the present global questioning of educational traditions, because of its unique history. Optimists could see it as reaping the benefit of being able to innovate rapidly because of the extremely decisive movement towards a commitment to education from the 1960 s onwards, and because of its longer familiarity with finding pragmatic ways of coping with both majority expectations and minority rights in the larger Canadian context. Many battles against extreme conservatism have already been won, or partly won. Though far from perfect, this approach to innovation has resulted in a model that is now increasingly committed to a recognition of differences in education, a model oriented toward the creation of a peaceful, equitable yet economically successful, industrialized society.

\section{Culture and Education in Quebec: A Historical Perspective}

Quebec is the largest Canadian province, geographically; it is three times the size of France. Its population is far smaller than that of France, however, around seven and half million people 
(Gouvernement du Québec, 2001c). Much of Quebec is covered with northern boreal forest or tundra, but most of the population lives in the more fertile southern area, in and around the valley of the St. Lawrence River. About 80.9 percent of Quebec's population speak French as a first language and are known in Quebec and Canadian idiom as "francophones." First Nations and Inuit, many of them still speaking their indigenous languages, form a very small part of the population, numerically, but are culturally very distinct and in some cases occupy large northern territories. The other inhabitants are a significant English-speaking minority ("anglophones"), who form about 8.3 percent of the population and have certain historically protected rights. In addition, there are an increasingly large number of speakers whose origins are from non-English or French-speaking countries ("allophones"). They form 9.3 percent of the population (Gouvernement du Québec, 2003). In addition, some 25,000 new immigrants settle in Quebec annually.

The 1867 British North America Act that established Canada as a Dominion under the British Crown gave each province the right to make its own policy in education, with certain established rights being entrenched in the BNA Act itself. The provinces continue to guard their rights over education fiercely. This means that it is impossible to generalize about education in Canada, even if there are some broad national and North American norms in the ways public schools are organized and run. Currently, for example, Quebec's institutions, evaluation policies and curriculum are in some ways quite different from those of its western neighbour, Ontario, or the Maritime provinces to the east.

Many of the indigenous peoples have federal agreements for their own protected land areas, although they are also affected by provincial legal controls or de facto systems of power - a situation that often causes tension. Much cultural damage still remains in many of these communities from the most repressive aspects of the colonial era (see, for example, Battiste \& Barman, 1995; Hill \& Stairs, 2002). Particularly damaging was the legacy of former residential schools in which indigenous children were separated from their families, forbidden the use of their own language, and forced into Christian religious practice. The Inuit of northern Quebec and the Cree, in a large area radiating out from James Bay, are two of the largest indigenous populations and both have special educational agreements with the Quebec government. Nine other indigenous peoples in Quebec include Mohawk, Montagnais, and Algonquin. Some First Nations have established control of their own on-reserve schools, in which the indigenous languages are now taught, at least at elementary (primary) level. The children of the Inuit of Northern Quebec use Inuktitut in school through early elementary years, with English or French phased in later.

Traditional anglophones, many of English, Scots, Welsh and Irish origin, tend to be clustered in and around Montreal and west to the Ontario border. There are also remnants of historical anglophone communities elsewhere in the province. Allophones in Quebec mostly live in and around Montreal, sometimes in quite well-defined neighbourhoods, and increasingly in ethnically mixed areas (McAndrew, 2001). Some of these areas include outlying urban suburbs, as later generations establish themselves economically and move out from the original inner-city quarters occupied by new immigrants. Inter-marriage between people of different ethnicities and both anglophone and francophone parentage is also increasingly common. Bicultural and multicultural experience is becoming familiar to most urban children, especially in the Montreal area.

Historically, this situation was arrived at by waves of European and, later, global immigration into the original lands of indigenous peoples. After Jacques Cartier claimed the region for the French crown during his voyage of $1534-35$, settlement began in 1608. By 1672 there were 10,000 people settled in New France. In the earliest period, their interests were largely in fur-trading with the local peoples and subsistence farming. Through a strong evangelistic movement, the Roman Catholic Church began to send clergy from France with a mission to educate and convert the indigenous peoples as well as to serve the spiritual and educational welfare of the colony. The Jesuit order, for example, was very active and founded the first boys' school in Quebec City in 1635. They were also interested, for missionary purposes, in indigenous languages and in some case provided the first detailed written records of them. One of the important consequences of this contact was that some early French settlers had close interactions with local peoples and learned useful survival skills from them in an extremely demanding environment with up to six months of snow and extreme cold. In many cases, however, the colonists' missionary fervour and need for land, and the native peoples' refusal to be assimilated into 
"European" life, led to resentment and alienation, a legacy still visible today.

In New France, settlement and farming allowed the development of a rural economy of large families; the major authority in their daily lives was the Church. Education operated through home and church for a long period. Gradually more and more rural villages began to open their own parish schools, mainly to teach basic reading and the catechism. After decades of sporadic warfare with English colonies, the Treaty of Utrecht (1713) allowed a period of peace and development. During this period of growing prosperity, educational provision began to increase. However, the Seven Years War between England and France (1756-1763) inaugurated a disastrous period for the French colonists, with the famous battle on the Plains of Abraham in Quebec City (1759) being seen as a key moment of humiliating and painful defeat (if viewed from the francophone perspective) or triumph (if viewed from the British viewpoint of the time).

In the wake of the defeat, some colonists and church leaders returned to France, and many villages were damaged or destroyed, with consequent educational disruption. The curious and often uneasy historical balance between conquerors and conquered is aptly symbolized by the fact that both generals, Wolfe and Montcalm, died during or just after the battle, and both have monuments today near the battle site. Even now, cultural history in each of Canada's official languages treats these events differently, though - as is often the case - the once defeated side, now the Quebec majority, has devoted more energy and emotion to keeping the memory of this earlier era alive, in oral tradition, music, fiction and film. In one famous Quebec novel, Les Anciens Canadiens, by Philippe Aubert de Gaspé, written in 1863 but set in the Conquest period, the central story concerns two friends educated together as boys in Quebec city, one French, the other a descendant of a Frenchwoman and a Scottish Highlander, who later find themselves on opposite sides. This theme is taken up again and again in various ways in Quebec literature. Another famous novel, written by Hugh McLennan in the1940s, brought the phrase "the two solitudes" into the Canadian idiom. Ironically, McLennan's purpose, like that of the German poet Rilke who coined the phrase, was to say that "love consists in this; that two solitudes protect and touch and greet each other."
After the conquest, a set of paradoxes developed. The British crown initially planned to assimilate the francophones and convert them to the Protestant faith and English. However, the new rulers rapidly realized the impossibility of assimilating a much larger, widely scattered and very resistant majority population who spoke a different language. As Pierre Graveline (writing from the secular and union tradition which has often, in Quebec, been strongly anti-clerical) comments, the Catholic church of the time made a deal with the British rulers:

Elle cherche à se faire reconnaître par le pouvoir colonial et tente de récuperer certains de ses privilèges et de ses biens. À cette fin, le haut clergé n'hésite d'ailleurs pas à prêcher la loyauté envers la couronne britannique et la collaboration avec les autorités coloniales.

[The church sought to be recognized by the colonial power and tried to recuperate some of its privileges and goods. With this goal in mind, the higher clergy did not hesitate to preach loyalty towards the British crown and collaboration with the colonial authorities.] [My translation] (Graveline, 2003, pp. 24-25).

The Quebec Act of 1774 reinstated the right for Catholics to worship as Catholics, reintroduced the former legal system, and reinstated land-owning and church rights. As Graveline also says,

Pendant toute cette période, le pouvoir brittannique hésite continuellement entrele tenta tion toujours présente de mettreen oeuvre des politiques pour soumettre et assimiler les Canadiens français et une approche plus pragmatique qui le conduit à rechercher des compromis avec l'élite canadienne-française et le clergé catholique afin de maintenir la paix sociale dans la colonie.

[Throughout this period, the British authorities hesitated continuously between the ever-present temptation to enact policies to dominate and assimilate the French Canadians and a more pragmatic approach that led them to seek a compromise with the French-Canadian elite and the Catholic clergy, in order to maintain social peace in the colony.] [My translation]

It is interesting to note that key concepts - recognition; social peace; the acceptance of different systems of rights (even if reluctantly given) - were present hundreds of years ago. They have continued ever since, in what can seem as an extraordinary political balancing act that the leaders of what is now Canada and what is now Quebec have engaged in over the years. 
During the nineteenth century a strong secular populist movement also gathered force. It was influenced by intellectual developments in Europe. Among its modern legacies is a still-strong trade union tradition and a pride, especially among francophones, in "la collectivité" - the social group or community that sees its survival as being dependent on solidarity. Partly because of a long history of poverty, only mitigated by local communities "pulling together" in difficult times, many Quebecois have developed a strong profile of working towards social progress, even for the underprivileged. The government now spends more on education per capita than any other Canadian province.

The British North America Act of 1867 enshrined the rights of both Catholic and Protestant minorities to have their own schools in Quebec City and Montreal and the right of dissent elsewhere. The legal and social acceptance of denominational difference as a basis for schooling remained in place until very recently. When I came to Quebec in 1983, for example, the system of public school boards in Montreal was still organized as either Catholic (usually French) or Protestant (usually English), though many of the schools, especially in the Protestant sector, actually served a wide variety of faiths and languages. I taught senior students in one urban high school, officially part of the Protestant School Board of Greater Montreal, where the student population was 96 percent Greek and Portuguese - none of them Protestant.

The Catholic school system began to receive most new immigrants, however, whatever their language and culture of origin, as a result of a series of language laws (Bill 63; Bill 22; Bill 101) in the late 1960s and 1970s. These laws were introduced as francophones became alarmed at the way new immigrants tended to gravitate towards English. Meanwhile the birth rate among francophones was dropping rapidly. The place of French seemed increasingly threatened, and political energy, through the Parti Quebecois, began to focus on this issue. Much to the frustration of the anglophone community, the laws restricted access to English language schools and strengthened the role of French as the official language in Quebec. In keeping with this legal position, that Quebec is officially a French-language province, Bill 101 decreed that all children in Quebec would have to study in the French system unless one or both parents had been educated in English in Quebec. Later this was altered, after a Canadian Supreme Court decision, to a parent educated anywhere in Canada. From the late 1970s, new immigrants, many of them from developing countries, could not choose to send their children to English schools. Instead, the children often entered "classes d'accueil" - welcome classes - which sought to give them some initial familiarity with the French language and mainstream Quebec culture.

The French Catholic school system, which had, up to that point, put most of its energies into maintaining a strong sense of social cohesion for the francophone culture and the French language, came face to face with the reality of pluralism in the classroom. Many of the reforms of the 1990s, and the years since, have sought to take account of this shift. Now, there is a major emphasis on understanding and recognizing cultural diversity. The change is not without its critics from conservative elements, however. In a culture that feels embattled by the international forces of globalisation and the central place of English-speaking commerce in that process, the preservation and celebration of Quebec francophone culture continues to be a preoccupation.

From the 1980 s to today, feminist, community and social justice groups have also been articulate critics of governments, as the neo-liberal agenda began to appear in Quebec corporate and political environments. In many decisions on social policy, Quebec's population still thinks and acts differently from those in English-speaking provinces. Cross-Canada polls regularly reveal a unique profile of opinion in Quebec. For example, university education for undergraduates is still much cheaper in Quebec than any other Canadian province. Privatisation of the kind that happened in the United Kingdom in the Thatcher era is not popular; "big government" and high taxes have remained in place to fund the education system, the health system, and the social safety net. There is still a wide variety of supports for underprivileged groups. The new Liberal government of Premier Jean Charest is trying to move towards a sterner economic approach, but is already, predictably, running into fierce opposition from strong forces in Quebec society, especially the unions.

The school realities of the Montreal area, an urban centre of three and a half million people, are particularly complex. Some immigrant groups of long-standing, such as the Jewish, Armenian and Greek communities, which arrived when religious difference was still a basis for separate schooling, were able to establish schools of their 
own. Their language, culture and religious tradition were taught, as well as French and English. The communities that established such schools have continued to run them, funded by the Quebec government and following the provincial curriculum, but often with longer school hours to accommodate the learning of their other language as well. Members of these communities who arrived more recently, however, come under the provisions of Bill 101. Their children must normally attend the French language school system. This led to a long-term decline in the English school population, though it is still substantial in the Montreal region and towards the Ontario border.

The change from religious to linguistic school boards finally occurred in 1997. Some school cultures were compelled to face new relationships and realities in many contexts. This has meant the amalgamation of certain school boards, and some schools "crossing over" from one school board to another. Historically, for example, English-speaking Catholics in Montreal, such as the large Irish community, had formed a sub-group in the Catholic school board. Many people now feel that children should learn at school about all religions, in a comparative perspective (Henchey, 1999).

The linguistic profile is further complicated by the fact that Quebec's English speaking minority - those who opted to stay on in Quebec through the political upheavals of the 1960 s to $1990 \mathrm{~s}^{2}$ - are now firmly convinced of the need for their own children to be fluent in French. Otherwise those children's only options as adult workers would be to leave Quebec or to work in a tiny subsection of the economy. Many schools in the English boards therefore operate with partial or full "French immersion" programs that have developed enormously in the last twenty years, and are explicitly recognized in the new curriculum. Many subjects are taught in French to these Anglophone children. Although the Francophone majority can expect to live and work throughout the province in their own language, there is now a growing consciousness of the economic value of English in the Canadian, North American and global contexts. English is now introduced a year earlier than before in the French elementary schools, and many francophone parents - while supporters of the measures to protect French - are keen for their children to gain experience of using English in leisure, education and cultural activities. Otherwise, the children's main exposure would be through popular culture and media, hugely dominated by the US commercial television stations, Hollywood, and a very different political ideology. This new bilingual openness on both sides of the former barrier reveals a greater confidence in identity; from a secure position it seems easier to be willing to open up to the other language.

Quebec in general, and Montreal in particular, have thus developed an "elite bilingual" - and indeed often trilingual population (De Mejia, 2002). This group has great potential advantages in local, provincial, national and even international professional life. Fully 50 percent of adult workers in Quebec have a strong command of both English and French, so that the once severe barriers to linguistic and cultural understanding seem to be giving way to a more easy-going acceptance of "the Other".

Again and again, what can be seen in Quebec's approach to education is the legacy of those early decisions, some religious, some economic, some political, and some linguistic, but all tempered by pragmatism and an unwillingness to return to the destruction and bitterness of the past. It is this pragmatism that has kept the "paix sociale" through a continuous process of recognition of often contradictory rights.

\section{The Reform: An Overview}

Quebec's latest reform has been in process since the mid-1990s. A previous large scale reform took place in the early 1980s. That reform was more skills-oriented, and of course did not envision the global and technological changes that have occurred since. It was also much more "top-down" and less attentive to community, parent and teacher opinion. In the $90 \mathrm{~s}$ a series of public meetings were held, leading to the Estates General of 1996-1997 and the Inchauspé report (Gouvernement du Québec, 1997). The new curriculum has been based on a great deal of consultation and international education research as well as the contributions of many committees, made up of mixed groups: university education specialists, government officials, professional researchers and, most significantly, teachers. A desire for continued democratic involvement has been illustrated by an extensive set of pilot projects in certain schools, response and evaluation sessions by teachers, and related publications and web-sites.

Among the key reforms is the change from academic years to two-year cycles: Cycles one, two and three in elementary school 
(grades 1-2; 3-4; 5-6). High school is divided into a common Cycle one secondary (grades 7 and 8 ); followed by the beginnings of differentiation into more varied options (Cycle two secondary; former grades 9-11). Only Cycle one of the high school curriculum has yet been published - this year 2004 - and there are still some undecided elements in the final curriculum for the remaining years.

Another element of the reform consists of changes in school governance. In principle, these changes should give the school administration, teachers, parents and the community more say in the local school's goals and development, through governing boards. The goal is to encourage, and facilitate much greater differentiation and responsiveness to local needs, based on community priorities and the profiles of students. Moreover, integration of students with special needs has become the norm.

\section{Curriculum in the Schools}

In a nutshell, the school curriculum reform documents are shaped by the goal of educating the whole person to be a lifelong learner capable of working in the global context and in future cultural, social, technological and job-related contexts that are impossible to predict in advance. In other words the aim is to shape citizens who will be flexible and autonomous as learners as well as equipped with skills, knowledge and a positive sense of self. Cross-curricular competencies and broad areas of learning are specified alongside subject area knowledge. The term "competencies" (French "compétences") is defined in the following way:

A set of behaviours based on the effective mobilization and use of a range of resources.... One aim of a competency-based program is to ensure that students' learnings serve as tools for both action and thought.... Unlike a skill, which may be applied in isolation, a competency makes use of several resources and is itself used in fairly complex situations. (Gouvernement du Québec, 2001b, p. 4)

Although this unfortunate translation using the word "behaviours" for the French "savoir-agir" - "knowing how to act" - may set off alarm bells in many minds, the competency approach as used here is designed to be evaluated by detailed and long-term interaction with the individual student. The student is seen as being at the centre. The competency is a complex and culturally-based set of abilities, knowledge and self-knowledge. It is not designed to lend itself to simplistic paper-and-pencil testing or to be broken down into hundreds of discrete outcomes of a limited kind that can then be documented mechanically. On the contrary, project-based learning and qualitative assessment are central to the reform; a variety of evaluation methods are encouraged. Both learning and evaluation are seen as dependent on the work of the teacher as a highly informed professional facilitator and evaluator. Among the key elements is student self-evaluation, so that the student becomes increasingly capable of making decisions independently and taking ownership of learning.

The over-arching cross-curricular competencies are:

- Intellectual: to use information; to solve problems; to exercise critical judgement; to use creativity;

- Methodological: to adopt effective work methods, to use ICT (information and communication technologies);

- Personal and social: to construct his/her identity; to cooperate with others;

- Communication-related: to communicate appropriately.

These are to be considered and evaluated by the teachers and school administrators in teams, both within and across the various activities of school life, in class and beyond, and with the close and careful involvement of parents.

Broad areas of learning are equally targeted. These are:

- Health and well-being;

- Personal and career planning;

- Environmental awareness and consumer rights and responsibilities;

- Media literacy;

- Citizenship and community life.

The subject areas are:

- Languages: English or French language arts; French or English as a second language; a third language (possibly);

- Mathematics, science and technology;

- Arts education: visual arts, music, drama; dance (though many schools will not have resources for all four);

- Social sciences (or, in the curriculum, the phrase "l'univers 
social" - "the social world"): history, geography and citizenship education; understanding the contemporary world;

- Personal and social development; physical education and health; ethics and religious culture.

(Gouvernement du Québec, 2001b).

Because of the long-entrenched power of the religious educational committees and the BNA Act, this last competency, which some argued should simply offer the students instruction in general and comparative religious cultures, has added to it three options of which students must choose one: moral education, Protestant, or Catholic religious instruction. This is the last vestige of the earlier confessional educational systems, and sits somewhat oddly in a document that otherwise promotes a strong sense of pluralist openness and secularization of schools.

Some of these curricular elements are of particular interest to the focus of this article, given Quebec's history. Space allows for only two examples: languages and citizenship. The initial statement on languages defines the value of mastery of one language, then continues:

Knowing several languages allows us to both enrich our knowledge of our mother tongue and to gain a better perspective on our cultural heritage. Moreover, learning a second or third language is one of the most important tools for advancing personal development in a pluralistic society that is open to other cultural realities. (Gouvernement du Québec, 2001b, p. 70)

The "Broad area of learning: Citizenship and community life," in the Elementary Curriculum, includes this:

As learning communities and microcosms of society, schools bring together students of diverse social and cultural origins. This makes the school an ideal place to learn to respect others and accept their differences, to be receptive to pluralism, to maintain egalitarian relationships with others and to reject all forms of exclusion. The school places students in situations that confront them on a daily basis with challenges related to cooperation in a spirit of mutual aid, solidarity, openness to others and self-respect. It gives them an opportunity to experience the democratic principles and values that form the basis for equal rights in our society. (Gouvernement du Québec, 2001b, p. 50)
The Social Sciences section of the secondary program, Cycle one, includes the following:

One of the challenges facing a pluralistic society like that of Quebec is to reconcile shared membership in a community with the diversity of identities. Students must develop a sense of who they are relative to other individuals characterized by numerous differences.... Constructing one's social identity, intentionally and thoughtfully, involves seeking to discover the origin of difference and specificity and the factors that explain them. This process enables students to understand that their identity is both personal and plural and that pluralism is not incompatible with the sharing of values, particularly those related to democracy. The study of past and present social phenomena helps people become aware of the historical foundations of their identity. (Gouvernement du Québec, 2004a, p. 306)

Citizenship, as I hope the previous account of Quebec's history will illustrate, is probably one of the most sensitive and contentious of all areas. Even the question "Citizenship in what state?" is a perfectly possible one. Quebecois leaders, for example, often use the word "national" with very deliberate political intent. Whereas other provinces in Canada have Legislative Assemblies, Quebec has "L'Assemblée Nationale." Separatism, in which the goal is to make Quebec a sovereign country, is perhaps less widely supported now than in some periods of the recent past but is far from dead as a political ideal. How this part of the curriculum is taught will, then, vary widely in different constituencies. Undoubtedly this is of great importance for the future. But the invitation (or challenge) has been made in the new curriculum: face up to cultural differences and find ways to construct and negotiate identity issues peacefully.

Clearly there are many challenges. The combination of "pressure" and "support" (Fullan, 1991) for teachers and administrators is beginning to be felt. Yet at this point the crucial question is the willingness - or not - of the teaching profession to bring this new curriculum into reality, whether in French-speaking, English-speaking, or other schools.

\section{Teacher Education Reform}

Quebec, like many other educational jurisdictions, is currently going through a huge demographic shift in the teaching population. The 
massive cohort of post-war baby-boomers hired in the $60 \mathrm{~s}$ and $70 \mathrm{~s}$ is retiring. A new generation is coming in to the profession. So teacher education is equally under the microscope in the context of the new curriculum. The expectations of future teachers as professionals are increasing. Here the Ministry of Education takes a far more active role than in most other jurisdictions. This has led to resistance by some universities, but acceptance by others that the generally agreed goals are indeed needed. Again culture, pluralism, acceptance of global change, and a strong sense of professionalism and support for democratic processes are central.

Twelve professional competencies are now expected of new teachers at graduation. Here professional competencies are defined as follows:

Generally, a professional competency is applied in a real-life professional setting; follows a progression from simple to complex; is based on a set of resources; is based on the ability to mobilize resources in situations requiring professional action; involves a successful, effective, efficient, recurrent ability to act; is part of intentional practice; and is a project, an on-going pursuit. (Gouvernement du Québec, 2001a, p. 43)

These teaching competencies are:

1. To act as a professional inheritor, critic and interpreter of knowledge or culture when teaching students.

2. To communicate clearly in the language of instruction, both orally and in writing, using correct grammar, in various contexts related to teaching.

3. To develop teaching/learning situations that are appropriate to the students concerned and the subject content with a view to developing the competencies targeted in the programs of study.

4. To pilot teaching/learning situations that are appropriate to the students concerned and to the subject content with a view to developing the competencies targeted in the program of study.

5. To evaluate student progress in learning the subject content and mastering the related competencies.

6. To plan, organize and supervise a class in such a way as to promote students' learning and social development.
7. To adapt his or her teaching to the needs and characteristics of students with learning disabilities, social maladjustments or handicaps.

8. To integrate information and communication technologies (ICT) in the preparation and delivery of teaching/learning activities and for instructional management and professional development purposes.

9. To cooperate with school staff, parents, partners in the community, and students in pursuing the educational objectives of the school.

10. To cooperate with members of the teaching team in carrying out tasks involving the development and evaluation of the competencies targeted in the programs of study, taking into account the students concerned.

11. To engage in professional development individually and with others.

12. To demonstrate ethical and responsible professional behaviour in the performance of his or her duties.

(Gouvernement du Québec, 2001a, p. 157)

Competency 1 insists on the teacher being capable of knowing and communicating the cultural inheritance and being able to interpret and critique the contemporary knowledge-base, both within the subject area and more widely. This implies a comparative stance. Competency 7 , though mainly addressed to the inclusive classroom in terms of special needs, also (in practice) asks teachers to be alert to students' diversity in every way; differentiated learning is central. Competencies 9-12 insist on social processes, communication, and connection with others in the school and community. In the reality of contemporary Quebec, where even the teaching population is becoming more and more diverse, this means that the teacher needs to be capable of bridging cultures. Communicating with parents demands this too, and may mean reaching across vast differences of language, culture, class and life-experience. Instead of two - or more - solitudes unable to help children, the goal now is closer to "third space" thinking where it is possible to remain strongly rooted in one's own context while being constantly able to work within a shared space with people of other cultures and contexts (Kelly et al., 2001). 


\section{The Challenge of Rights, Recognition, and School Practice:} Questions for the Future

The recent set of changes in education in Quebec has been almost dizzying in its speed and depth. Some paradoxes have developed how can the teacher education programs for secondary teachers be confirmed when the whole curriculum and end-of-high-school evaluations have not yet been developed? How many changes can any school and school board cope with at once? What are the dangers of destabilizing an existing system that in some areas - such as the teaching of secondary mathematics - has already come very high in international OECD tests? Can all the reforms be successfully realized when funding for counsellors, psychologists, social workers, and school resources and infrastructure remains a constant problem? Just how much are teachers themselves expected to do? Are the twenty-first century goals found everywhere in the Reform documents more than idealism?

A book like Allan Neilsen's Daily Meanings is perhaps one that all curriculum reform specialists should read, revealing as it does, through teacher autobiographies, some of the real-world problems that can undermine even the most enlightened of goals: resentful administrators or colleagues; conservatism and prejudice; inadequate resources; a high incidence of social dysfunction in the community; isolation; a general feeling among teachers that they are blamed in the media for all of society's ills and given credit for none of the successes. These problems are unlikely to go away. Both internal and external support and challenge are needed if a reform such as this is to work, heralding a positive culture in which the next generation of children can grow up with a confidence in their own identity, culture(s) and language(s) as well as the willingness to listen to, and accept, those of others.

The sense of empowerment and openness enshrined in the new curriculum and teacher education reforms have to happen for both students and teachers if they are to happen at all. Curriculum documents like these are always an idealization of a much more messy reality. The Quebec Education Reform, however, offers a fascinating open door to the future of Quebec society as a part of global society - if, as has happened so often in the past, political, economic, linguistic, religious and cultural tensions can somehow be kept in balance.

\section{Notes}

1. CEGEPS-Colleges d'enseignment générales et professionelles-were founded in 1967. The CEGEPS are unique in Canada, educating most of Quebec's 17-19 year old (and sometimes older) students who are in diploma and pre-university programs, in a public system. Both academic and some professional and vocational areas are taught, and all students take some core courses together. This means that there is far more mixing of different student populations, whatever their socio-economic and ethnic background, than is generally the case. The future of CEGEPS is, however, currently under discussion.

2. These upheavals included the October crisis, (when a small but violent separatist group, the Front de la Libération du Québec, or FLQ, sought to use kidnapping and bombs to advance their cause. A cabinet minister, Pierre Laporte, was killed and British diplomat James Cross was kidnapped but survived). This period also included two referenda on moving towards independence, and Bill 101. All of these are extremely sensitive and contentious issues in Quebec to this day.

\section{References}

Aubert de Gaspé, P. (1994). Les anciens Canadiens. Québec: Bibliothèque Québecoise. (First published in 1863 by Desbarats et Derbishire)

Battiste, M., \& Barman, J. (1995). First Nations education in Canada: The circle unfolds. Vancouver, BC: University of British Columbia Press.

De Mejia, A-M. (2002). Power, prestige and bilingualism: International perspectives on elite bilingual education. Clevedon, UK: Multilingual Matters.

Fullan, M. (1991). The new meaning of educational change. New York: Teachers' College Press.

Gouvernement du Québec. (1963-1966). Report of the Royal Commission of Inquiry on Education in the Province of Quebec. Vols. 1-5. (The Parent Report). Québec: Gouvernement du Québec.

Gouvernement du Québec, Ministère de l'Éducation. (1996). The estates general on education 1995-1996: The state of education in Quebec. Québec: Gouvernement du Québec.

Gouvernement de Québec, Ministère de l'Éducation. (1997). Reaffirming the mission of our schools: Task force on Curriculum Reform. Québec: Gouvernement du Québec. 
Gouvernement du Québec, Ministère de l'Éducation. (2001a). Teacher training: Orientations, professional competencies. Québec: Gouvernement du Québec. [Original French title: La formation à l'enseignement: Les orientations, les compétences professionelles.]

Gouvernement du Québec, Ministère de l'Éducation. (2001b). Quebec education program: Preschool education, elementary education. Québec: Gouvernement du Québec.

Gouvernement du Québec, Ministère de l'Éducation. (2001c). Education in Quebec in brief. Québec: Gouvernement du Québec.

Gouvernement du Québec, Ministère de l'Éducation. (2003). Studying in Quebec: For foreign students wishing to study in Quebec. Québec: Gouvernement du Québec.

Gouvernement du Québec, Ministère de l'Éducation. (2004a). Quebec education program: Secondary school education, Cycle one. Québec: Gouvernement du Québec.

Gouvernement du Québec, Ministère de l’Éducation. (2004b). Education Quebec: History.

$<$ www.meq.gouv.qc.ca/rens/brochu/anglais/history.htm >

Gouvernement du Québec, Ministère de l'Éducation. (2004c). Education Quebec, Home page (English version). $<$ www.meq.gouv.qc.ca/GR-PUB/m_englis.htm >

Graveline, P. (2003). Une histoire de l'éducation et du syndicalisme enseignant au Québec. Montréal, Québec: Editions Typo.

Henchey, N. (1999). The new curriculum reform: What does it really mean? McGill Journal of Education, 34(3), 227-242.

Henchey, N., \& Burgess, D. (1987). Between past and future: Quebec education in transition. Calgary, Alberta: Detselig Enterprises.

Hill, K. J., \& Stairs, A. (Eds.). (2002). Indigenous education: Ways of knowing, thinking and doing [Special Issue] McGill Journal of Education, 37(3).

Kelly, M., Elliott, I., \& Fant, L. (Eds). (2001). Third level, third space: Intercultural communication and language in European higher education. Bern: Peter Lang.

McAndrew, M. (2001). Immigration et diversité à l'école: Le débat québecois dans une perspective comparative. Montréal: Les Presses de l’Université de Montréal.
McLennan, H. (1945/2003). Two solitudes. Toronto: New Canadian Library.

Neilsen, A. (1999). Daily meaning: Counternarratives of teachers' work. Mill Bay, BC: Bendall Books.

Smith, W. J., \& Foster, W. F. (1999). Educational restructuring in Quebec: The third wave of reform. McGill Journal of Education, 34(3), 201-205.

Smith, W. J., Foster, W. F., \& Donahue, H. M. (1999). The transformation of educational governance in Quebec: A reform whose time has finally come. McGill Journal of Education, 34(3), 207-225.

Taylor, C. (1994). The politics of recognition. In A. Gutman (Ed.), Multiculturalism: Examining the politics of recognition (pp. 25-73). Princeton, NJ: Princeton University Press.

\section{The author}

Ann Beer is the Editor of the McGill Journal of Education and an Associate Professor in the Department of Integrated Studies in Education at McGill University in Montreal. She has published in the areas of literacy, bilingualism, literature, gender and autobiography, and is now engaged on a team research project with Dr Mary Maguire on multilingual children's identity construction in the Quebec context, funded by the Social Sciences and Humanities Research Council of Canada. 